Førsteamanuensis, Brynjar Foss, universitetslektor, Elisabeth Harbin og stipendiat, Lars Rune Sæterdal, Institutt for helsefag, Det samfunnsvitenskapelige fakultet, Universitetet i Stavanger
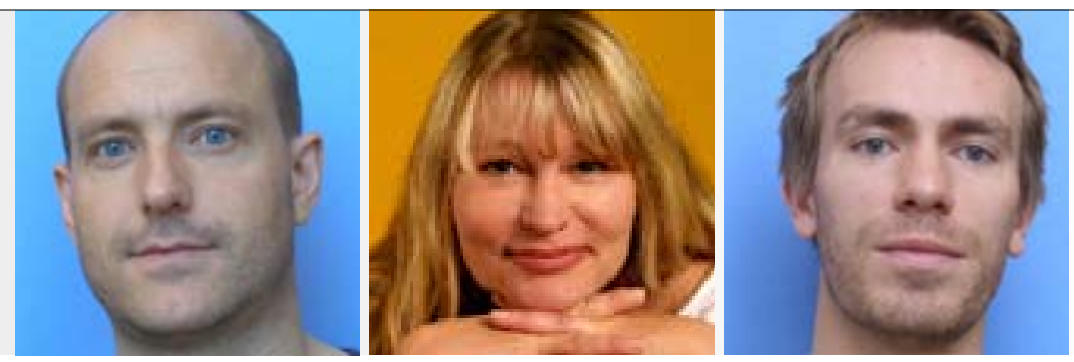

\title{
Mer enn støttefag
}

\author{
Solide basiskunnskaper i anatomi og fysiologi er nødvendig for \\ å utøve sykepleiefaget.
}

I Sykepleien 2/09 kan vi lese om deltidssykepleierstudenter ved Høgskolen i Oslo (HiO) som selv fikk velge hva de ville skrive om i sin anatomi og fysiologieksamen. Sammen med rammeplanens vage formuleringer viser dette tydelig at det trengs en avklaring av de biologiske fagenes betydning i sykepleierutdanningen og yrkesutøvelsen.

Ifølge rammeplanen skal man etter endt sykepleierutdanning ha kompetanse til å «informere, undervise $\mathrm{og}$ veilede pasienter $\mathrm{og}$ pårørende om problemer og behov ...» og «drive helseopplysning ...». Om de medisinske og naturvitenskapelige emner står det videre at hensikten med disse er blant annet «å få kunnskap om kroppens fysiologi ...» og at «kunnskap om menneskets normale utvikling og sykdomsprosesser er nødvendig for at en sykepleier skal kunne observere og i samarbeid med andre iverksette forebyggende, behandlende, lindrende og rehabiliterende tiltak».

\section{Behov for presisering}

Rammeplanen beskriver i høyeste grad en vag forstålse av relevansen til de biologiske fagene for sykepleiere. Dette kan gi store sprik i fortolkningen av fagenes verdi og i verste fall føre til en direkte undervurdering av fagenes relevans. Derfor er det behov for en presisering av de biologiske fagenes betydning for sykepleiere. Det er neppe feil å hevde at anatomi og fysiologi er støttefag for andre emner i sykepleierutdanningen. Men vår påstand er at det blir en for snever betegnelse, ikke minst på grunn av den raske medisinske utviklingen og det informasjons- og kunnskapssamfunnet vi er en del av.

\section{Helt grunnleggende}

Sykepleie er et yrke der man arbeider med mennesker. Mer presist kan vi si at sykepleie er et yrke der man jobber med syke og lidende mennesker eller med a forebygge at mennesker blir syke eller sykere. For å kunne lykkes i dette arbeidet, kreves det solide basiskunnskaper. Sykepleie er tverrfaglig og "grunnmuren» består i stor grad av kunnskaper om menneskekroppens anatomi og fysiologi. Svikter grunnmuren

\section{Lite er så avslørende som et mote med fagpersoner med manglende basiskunnskaper.}

vakler og eventuelt raser hele huset. Overført til sykepleie betyr dette at man neppe kan bli en god yrkesutøver uten nettopp inngående kunnskaper om kroppens oppbygning og funksjon. Å stå faglig støtt gir sykepleieren økt pasientsikkerhet, faglig identitet og yrkesstolthet.

\section{Yrkesutøvelse}

De biologiske fagene er utgangspunkt for flere andre emner som inngår i utdanningen. Dette er opplagt med hensyn til farmakologi og sykdomslære, men også i forhold til klassiske sykepleieroppgaver, som for eksempel observasjon av pasienter eller forebygging av komplikasjoner. Hvordan kan sykepleier tolke pasientobservasjoner, forstå medisinske beskrivelser eller vurdere om avvikende» prøvesvar er «normale» i forhold til pasientens diagnose/ behandling, eller om det er noe man bør reagere umiddelbart på, dersom de ikke forstår den fysiologiske sammenhengen?

Også i forbindelse med prosedyrer som sprøytesetting, nedlegging av sonde eller betjening av avansert medisinsk utstyr, er sykepleierens anatomi- og fysiologikunnskaper avgjørende for pasientens velvære og sikkerhet. Det samme gjelder ved administrering av legemidler og observasjon av effekt og eventuelle bivirkninger, for eksempel det å se sammenhengen mellom pasientens bruk av vanndrivende medikamenter, forstyrrelse av elektrolyttbalansen og arytmi.

\section{Pasientundervisning}

En annen sentral sykepleieroppgave handler om å undervise/veilede pasienter i forhold til å ta vare på egen helse. Hvordan kan man forklare eller lære en pasient noe man ikke selv forstår eller behersker? Tillit er en grunnleggende faktor i relasjonen mellom sykepleier og pasient, eventuelt pårørende. Vi vil hevde at denne tilliten i stor grad er bygd på pasienten/pårørendes opplevelse av sykepleierens faglige kompetanse. Selvsagt vil denne kompetansen bestå av flere komponenter, men sykepleierens basiskunnskaper om menneskekroppen er en grunnleggende stein i det tverrfaglige byggverket sykepleiefaget består av. Lite er så avslørende som et møte med fagpersoner med manglende basiskunnskaper.

Sykepleie er ikke bare et tverrfaglig fag, men handler i stor grad om å samarbeide tverrfaglig i team bestående av ulike profesjoner. Kvaliteten på dette samarbeidet er blant annet avhengig av at partene deler en felles kunnskapsbase, inkludert anatomi og fysiologi.

Man skal videre ikke undervurdere det faktum 


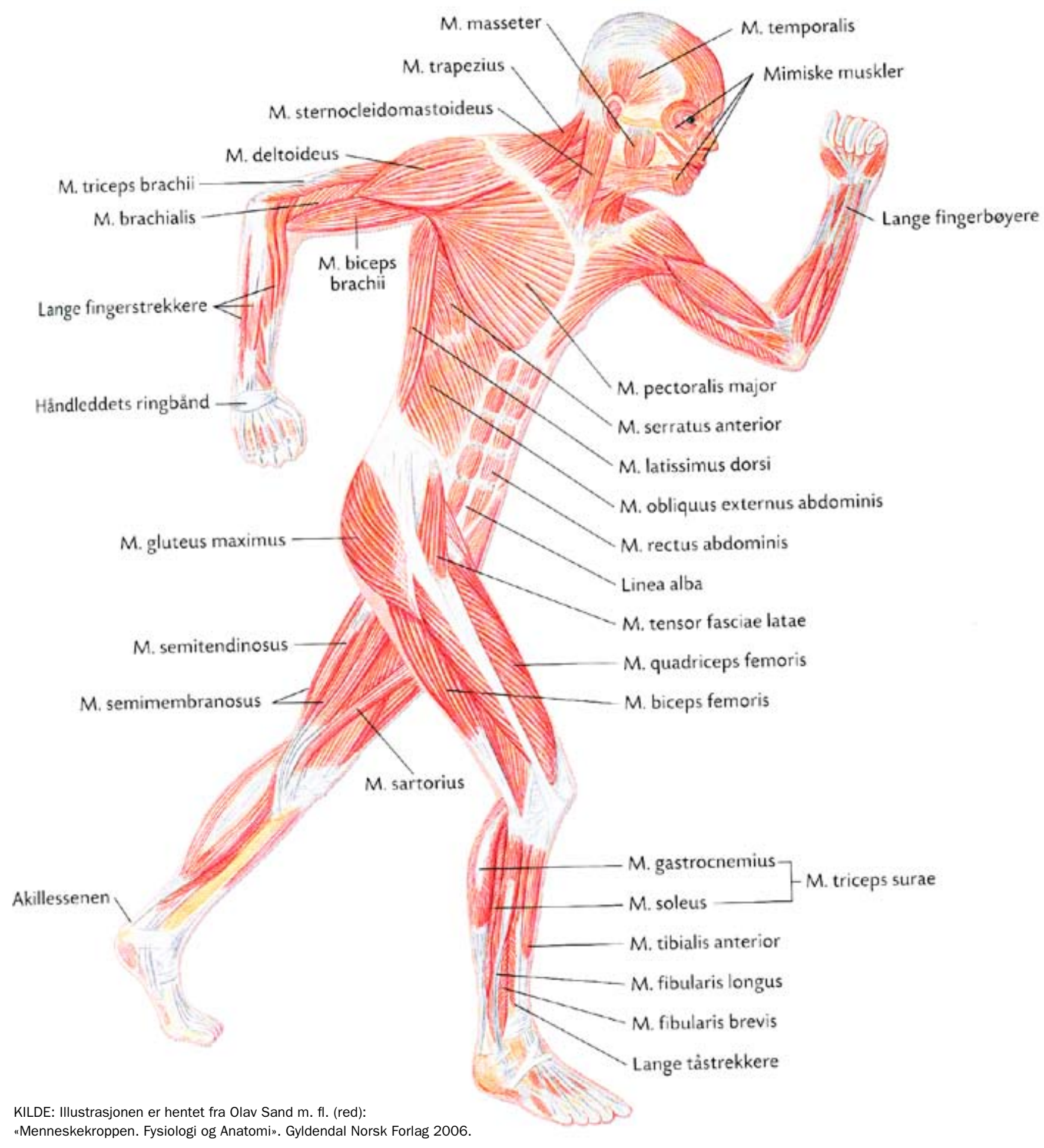

"Menneskekroppen. Fysiologi og Anatomi". Gyldendal Norsk Forlag 2006.

at helsevesenet kontinuerlig utfordres av nye medisiner og behandlingsformer. Medisinsk nyvinning bygger likevel på den samme grunnleggende anatomi og fysiologi. For å få kvalitet $\mathrm{i}$ helsevesenet, kreves det derfor kompetente sykepleiere som evner å anvende fysiologisk kunnskap. Behovet for slike sykepleiere blir det ikke mindre av i fremtiden!

\section{Fremtidens utfordringer}

Vi lever i et samfunn med tilgang på enorme mengder informasjon og kunnskap. Det er mulig å skaffe seg svært god informasjon om det aller meste, samtidig som utfordringen med å skille god og veldokumentert viten fra spekulasjon og synsing øker. Pasienten kan ha skaffet seg mye kunnskap (rett eller gal) om sympto- mer og sykdomsbilde allerede før kontakt med helsevesenet. Oftere enn før kommer pasienten til legen og har stilt sin egen diagnose, gjerne en diagnose legen ikke nødvendigvis kjenner særlig godt. I informasjonssamfunnet trenger sykepleiere to former for kunnskap; direkte fagkunnskap, og kunnskap om kunnskapen. La oss begynne med det første: Sykepleiere må 
være faglig teoretisk kompetente for å kunne informere og diskutere med pasient og pårørende om symptomer, sykdom og behandling på en slik måte at det både informerer og vekker tillit. Alle mennesker har et forhold til sin egen kropp, men ikke alle har en medisinsk tilnærming. Derfor vil det «friske mennesket» ofte være utgangspunktet for samtalene. Vi må i denne sammenheng ikke glemme at både farmakologi og patologi er anvendt fysiologi. Med andre ord; en godt fysiologisk skolert sykepleier vil være bedre rustet til å informere og diskutere faglige utfordringer med pasient/pårørende. For det andre må sykepleiere i stadig større grad, i tråd med tilgangen på kunnskap, være i stand til å skille svada fra dokumentert helsekunnskap samt være i stand til å ha et kritisk blikk på den kunnskap som presenteres i massemedia til enhver tid. Mye av kunnskapen som er lettest tilgjengelig via massemedia og internett, er ofte forenklinger og spekulasjoner, unyansert presentert, men som likevel fremstår som «sannheter». Dette må Helse-Norge forholde seg til. Det betyr i praksis at dette må også sykepleiere forholde seg til når jobbsituasjonen krever det. Igjen innebærer det at sykepleierne våre må være grundig skolerte i basalfagene.

\section{Undervurdert}

De biologiske fagene er undervurderte i norsk sykepleierutdanning sammenlignet med flere andre land. Ser vi til for eksempel Australia står de naturvitenskapelige fagene mye sterkere. Det gis flere timer undervisning, det inngår obligatoriske laboratoriekurs og pensum er betraktelig mer omfattende enn det som etter vårt kjennskap tilbys i Norge. Skal vi som driver med sykepleierutdanning øke våre studenters kompetanse og dyktighet, må vi styrke de bio-

\section{De biologiske fagene er under- vurderte i norsk sykepleierutdanning sammenlignet med flere andre land.}

logiske fagene. Ifølge rammeplanen er anatomi, fysiologi og biokjemi tildelt 12 studiepoeng av et studium på 180 poeng. Dette innfrir på ingen måte de faglige kravene man må kunne stille til sykepleierne innen grunnleggende biologiske fag. Derfor må institusjonene jobbe for bedre forhold for de biologiske fagene mot myndighetene, og særlig i utarbeidelsen av nye rammeplaner. Men vel så viktig er det å jobbe for disse fagene internt $\mathrm{i}$ institusjonen når det gjelder fordelingen av studiepoeng, pensumvalg og evalueringsformer.

\section{Kvalitetssikring}

Den faglige forbedringen og kvalitetssikringen av de biologiske fagene i sykepleierutdanningen kan økes på ulike måter. I denne sammenhengen kan et virkemiddel være å innføre forkunnskapskrav i for eksempel kjemi eller biologi, gi forkurs i disse fagene og/eller benytte bedre læremidler enn det som er praksis i dag, for eksempel litteratur med større faglig bredde og dybde. Vi stiller oss spørrende til om en eksamensordning der studenter selv kan plukke ut en mindre del av et grunnleggende emne kvalitetssikrer sykepleierstudentenes biologiske kunnskapsnivå. Samtidig er vi bekymret for at $\mathrm{HiO}$ ikke er den eneste institusjonen som undervurderer de biologiske fagenes betydning i sykepleierutdanningen og yrkesutøvelsen.

Vi må ikke glemme at sykepleierens hovedfunksjon i tillegg til å lindre symptomer, er å forebygge eller gjenopprette fysiologisk ubalanse. Grunnleggende fysiologikunnskap kan derfor ikke undervurderes.

\section{Fagnotiser}

\section{Melder færre bivirkninger}

Antallet bivirkningsmeldinger fra leger har gått ned med over 20 prosent siden 2005. I 2008 sendte leger inn om lag 1150 meldinger, mot 1250 året før. Det gir grunn til bekymring, mener Hanne Stenberg-Nilsen i Regionale Legemiddelinformasjonssentre (Relis), som tror en av årsakene kan være at legene ikke tar seg tid til å rapportere om bivirkninger i en travel hverdag. I tillegg kan meldeordningen slik den er i dag, med forskjellige meldeordninger for bivirkninger fra legemidler og andre typer produkter, virke forvirrende, mener hun. Nå vurderes forskjellige tiltak for å få legene til å rapportere mer. Kilde: Dagens Medisin

\section{Fikk pris for psykisk helsearbeid}

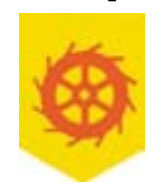

Lørenskog kommune har blitt tildelt Kreativitetsprisen 2008 for sin seriøse, brede og mangfoldige satsing på psykisk helse over flere år. Prisen deles årlig ut for å hedre den som står bak den beste markeringen av Verdensdagen for psykisk helse.

Ifølge koordinator for Verdensdagen, Torodd Eriksen, har kommunen gjennom en årrekke markert seg som et foregangssamfunn i det psykiske helsearbeidet. "Kommunen er et fellesskap. Ingen får gode helse av å være på utsiden, snarere tvert imot; det produserer dårlige helse og mistrivsel", sa ordfører Åge Tovan, da han på vegne av kommunen mottok prisen, som var et maleri.

\section{Leketerapi på Ullevål}

Barn som av ulike årsaker er lenge på sykehus, har behov for å gi uttrykk for hvordan de har det. Ifølge leketerapeut Mette Egenæss kan nettopp lek gi dem muligheten til det. Som en av fire førskolelærere med spesialkompetanse ved Ullevål, tilbyr hun barn et fristed uten fokus på sykdom. Det er ikke uvanlig at barnets sykdom gjenspeiler seg i leken, men det skjer i så fall på barnets premisser, sier hun. Nye medisinske ord og uttrykk blir ofte nevnt gjennom lek og samtaler med barna. Vi er her for å hjelpe barnet og familien til gode opplevelser og mestring i en sykehushverdag, sier Egenæss.

Kilde: ulleval.no

\section{Storstilt pasientunder-søkelse ved Haukeland}

Som første sykehus i landet foretok Haukeland universitetssjukehus i løpet av den 16. april, eller det såkalte "Helsedøgnet", en kartlegging av livsstilen blant 2000 pasienter. Kosthold, røyke- og alkoholvaner, samt fysisk aktivitet var blant faktorene som ble registrert. Disse risikofaktorene er ifølge overlege Svein Skjøtskift viktige i forhold til både sykdomsutviklingen og behandlingen av en rekke akutte og kroniske sykdommer og skader. For å kunne gi optimal behandling, må sykehuset vite mest mulig om pasientene, opplyser han. Kartleggingen ble utført av sykepleierstudenter, og de første resultatene vil bli lagt frem på en internasjonal konferanse i regi av Verdens helseorganisasjon (WHO) i begynnelsen av mai. Kilde: Helse Bergen 